\title{
Bacterial Contamination of Street Vended Food Pani Puri Available in Janakpurdham, Dhanusha
}

\author{
Nagendra Prasad Yadav ${ }^{1 *}$, Rakesh Kumar Yadav ${ }^{2}$ \\ ${ }^{1}$ Department of Microbiology, Model Multiple College, Tribhuvan University, Janakpurdham \\ 2Department of Pharmacology, Pakalihawa Campus, IAAS, Tribhuvan University, Janakpurdham \\ *Corresponding author: Nagendra Prasad Yadav, Department of Microbiology, Model Multiple \\ College, Tribhuvan University, Nepal Email: nagendrayadav2073@gmail.com.
}

\begin{abstract}
Objectives: To determine the level of bacterial contamination in food (Pani puri) available in market of Janakpur, Dhanusha, Nepal.

Methods: Total 120 samples of Pani puri (60 solid matters and 60 masalaa Pani) collected aseptically from the market were transported to the microbiology laboratory and processed for microbial count by serial dilution technique. Microbial load and presence of pathogen were detected in each sample.

Results: Analysis of the food samples revealed that $70 \%$ of Pani puri samples had high loads of bacterial pathogens such as Escherichia coli, Staphylococcus aureus, Klebsiella spp, Pseudomonas spp, Bacillus spp.

Conclusion: This study depicted that the street vended food Pani puri of Janakpur are highly contaminated with pathogenic bacteria which can cause health risk to consumers. Thus, it is suggested that regular monitoring of the quality of street foods must be practiced to avoid any food bone illness in future.
\end{abstract}

Key words: Pani puri, Hygiene, Bacteria, Contamination

\section{INTRODUCTION}

Street - vended foods are foods from street vendors which are ready to eat food (RTF) and drink prepared on the streets or at home and also sold in street or other public places, such as School, College, Universities, Market on fair, often from a portable food booth or food cart and are consumed on the streets without further preparation (Tambekar et al. 2011). Pani puri is very popular street food which is consumed by large amount of population of different age groups. The pani puri in Nepal has different names as Gol Gappa in Delhi, Phuchka in Bengal, Gup Chup in Chattisgarh or Pani Puri in Maharashtra evokes the same love at any part of the country. Gol Gappa is hollow puri, fried crisp and filled with a mixture of flavoured water (commonly known as imli pani), tamarind chutney, chilli, chaat masala, potato, onion and chickpeas. Pani puri is crowned as king of evening snack. This snack consists of three separate items i.e. pani, puri and masala. Wheat

Date of Submission: September 20, 2019

Published Online: December, 2019 flour is used to make puri in masala boiled or mashed potatoes mixed with spicies are used. The pani is sour water to which spices likes salt, pepper, mango powder, jalijeera etc. are added. In every puri, masala are added after making a hole in it and then spicy water is filled in this puri and served to the consumers in plate on site (Saxena and Agarwal 2013).

The most popular street foods in Nepal are Pani puri among consumers. Although it is very popular, easily available and cheap, it is frequently associated with various food borne diseases. Food borne illness associated with the consumption of street foods has been reported in several places in Nepal. Selling the foods on road side, unhygienic preparation and handling, in sufficiency in water supply for cleaning purposes, make the street food more contaminated and major sources of food borne diseases (Abdussalam and Kaferstein 1993).

Microbial contamination of ready-to-eat foods sold by

Date of Acceptance: November 26, 2019

DOI: https:/ / doi.org/10.3126/tujm.v6i0.26587 
street vendors and hawkers has become a major health problem as they are associated with diarrhoeal diseases due to their improper handling and serving practices (Barro et al. 2007). Street food vendors are mostly uninformed of good hygiene practices (GHP) and causes of diarrhoeal diseases (Mensah et. al 2002), which can increase the risk of street food contamination. The vendors can be carriers of pathogens like E. coli, Salmonella spp, Camplyobacter spp and $S$. aureus who eventually transfer these foods borne hazards to consumers (Mankee et al. 2003, Dawson and canet 1991). The conditions of street food preparation and vending raise many concerns for consumer's health are consumed by huge population and frequently associated with diarrhoeal diseases due to their microbial contamination.

Street vended Pani puri is popular and sold in almost all the cities throughout Nepal. Janakpur, popularly known as Janakpurdham is a sub-metropolitan city in Dhanusha District of Province No. 2 of Nepal which is famous for religious and cultural tourism. There are various pani puri stalls in the streets and chowks of Janakpur in the crowdy and clumsy areas where has huge crowd of consumers during the business hours. Golgappas particularly in summer and monsoons are the season that conducive to bacterial growth in food items. Unclean location, unhygienic serving practice, storage of aaloo and masala, unhygienic water, stalls present in dust and dirt area and the source of transfats in Pani puri are major concerns of health issues in the front of the eye of Janakpur municipality. But no any permanent strategy has been planned to establish the Pani Puri stalls in hygienic places with hygienic services.

A general lack of factual knowledge about the epidemiological significance of many streets vended foods, poor knowledge of streets vendors in basic food safety measures and inadequate public awareness of hazards posed by certain foods has severely hamperd the development of a precise. Although there is a growing demand for these food products, enough information is not available regarding the microbiological quality of these products. Therefore, this study was aimed to determine the level of microbial burden in Pani puri to establish the hygienic status of street vended food Pani puri and their impact in street foods contamination at different parts of Janakpur, Nepal.

\section{MATERIALS AND METHODS}

The present study was conducted in microbiology laboratory of Model Multiple College, Janakpurdham from February to July in 2018 AD. The different samples of Pani puri were collected from different Pani puri stalls of local areas as Ramanand Chowk, Shiv chowk, Janak chowk, Ram chowk, Bhanu chowk and Railway station sites of Janakpur market. A total of120 samples were collected. Each sample of Pani puri was fragmented into two different segments (the liquid masala pani and solid matter masala) and were collected in sterile plastic containers which were sealed and transported aseptically to microbiology laboratory for further processing.

For the microbiological analysis, serial dilution technique was used. After serial dilution, pour plate technique was applied on nutrient agar for bacteria. After solidifying, Petri plates were incubated at $37^{\circ} \mathrm{C}$ for 24 to 48 hours for the growth of bacteria in inverted position as per given in a monograph. After completion of the incubation period, the colonies appeared on the surface of NA media was counted in the petri plates. Total colony forming unit (CFU) was determined. The isolated colonies of organism were transferred into various selective and differential media and were identified by performing various biochemical tests.

\section{RESULTS}

A total of 120 Pani puri samples were analyzed. All the samples were processed for total count and pathogen identification and then result was interpreted. All the samples were examined for presence of microbial pathogens by pour plate technique. Among these $50(41.67 \%)$ samples were collected from the crowded vendors and $70(58.33 \%)$ samples from non-crowded.

The total viable count of bacteria in masala pani was found between $90-182 \times 10^{5}$ and $50-121 \times 10^{5}$ and solid matter masala is varied between $80-130 \times 10^{1}$ and $46-$ $118 \times 10^{5}$ from the crowded and non-crowded vendors respectively. The majority of samples were found to contaminate with different species of pathogenic microorganisms. Both pani masala $46(76.67 \%)$ and solid matter $38(63.33 \%)$ were found to be highly contaminated. Out of 120 samples analyzed, 84(70\%) were found to be contaminated by pathogenic bacteria. The common contaminants isolated and identified were E. coli 32(38.09\%), Salmonella 26(30.95\%), Staphylococcus aureus 38(45.23\%), Pseudomonas spp $18(21.42 \%)$, Bacillus $24(20.00 \%)$ etc. were the common isolates. Staphylococcus aureus and E. coli were the major contaminants of Pani puri. 
Table 1: Percentage of positive sample among total sample

\begin{tabular}{lcccc}
\hline Sample & Panimasala (60) & Solid matter (60) & Growth in Panimasala (46) & Growth in solid matter (38) \\
\hline Ramanand chowk & 5 & 5 & $04(80.00 \%)$ & $03(60 \%)$ \\
Ram chowk & 8 & 8 & $06(75.00 \%)$ & $05(62.5 \%)$ \\
Janak chowk & 17 & 17 & $12(70.58 \%)$ & $09(52.94 \%)$ \\
Shiv chowk & 16 & 16 & $13(81.25 \%)$ & $10(62.50 \%)$ \\
Railway station & 14 & 14 & $11(78.57 \%)$ & $11(78.57 \%)$ \\
\hline
\end{tabular}

Table 2: Bacterial contamination in crowded and non-crowded sample

\begin{tabular}{lccc}
\hline Bacteria isolated & Crowded samples (50) & Non-crowded samples (70) & Total \\
\hline E. coli & $22(44 \%)$ & $10(14.28 \%)$ & $32(38.09 \%)$ \\
Salmonella spp. & $15(30 \%)$ & $11(15.71 \%)$ & $26(30.95 \%)$ \\
Staphylococcus aureus & $30(60 \%)$ & $8(11.43 \%)$ & $38(45.23 \%)$ \\
Pseudomonas spp. & $10(20 \%)$ & $8(11.43 \%)$ & $18(21.42 \%)$ \\
Bacillus spp. & $20(40 \%)$ & $4(05.71 \%)$ & $24(20.00 \%)$ \\
\hline
\end{tabular}

Distribution pattern of contaminated samples of pani puri

Out of 120 samples analyzed, 84(70\%) were found to be contaminated by pathogenic bacteria and $30 \%$ were non-contaminates.

Distributed samples of pani puri

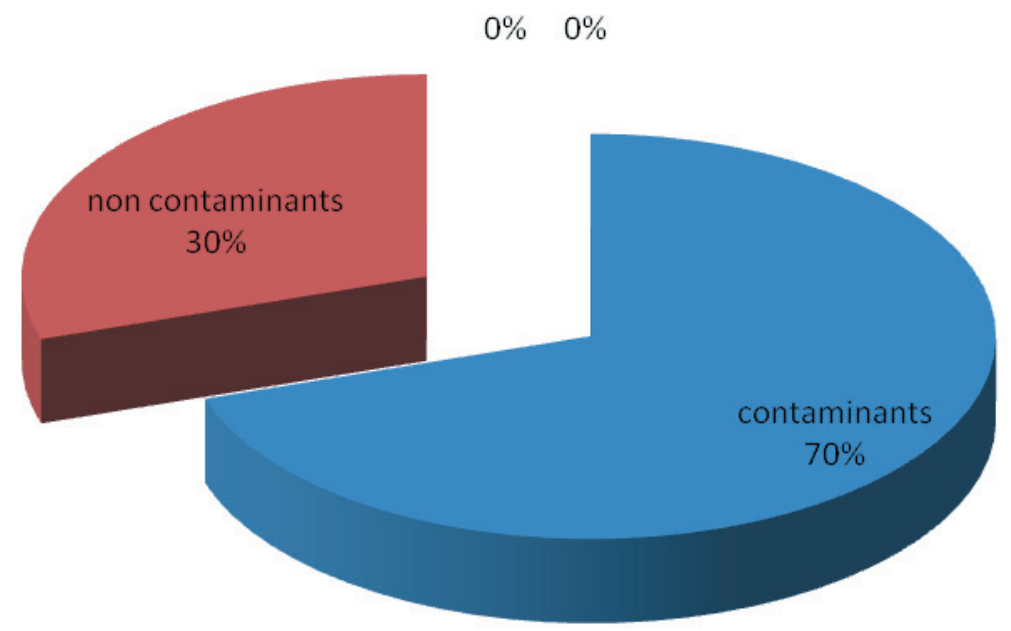

Figure 1: Distribution pattern of contaminated samples of pani puri

Bacteriological contamination of pani puri

Total five bacterial species were identified. Among them E. coli 32(38.09\%), Salmonella 26(30.95\%), Staphylococcus aureus 38(45.23\%), Pseudomonas 18(21.42\%) and Bacillus
$24(20.00 \%)$ etc. were the common isolates. Staphylococcus aureus and E. coli were the major contaminants of Pani puri. 


\section{Bacterium load in pani puri}

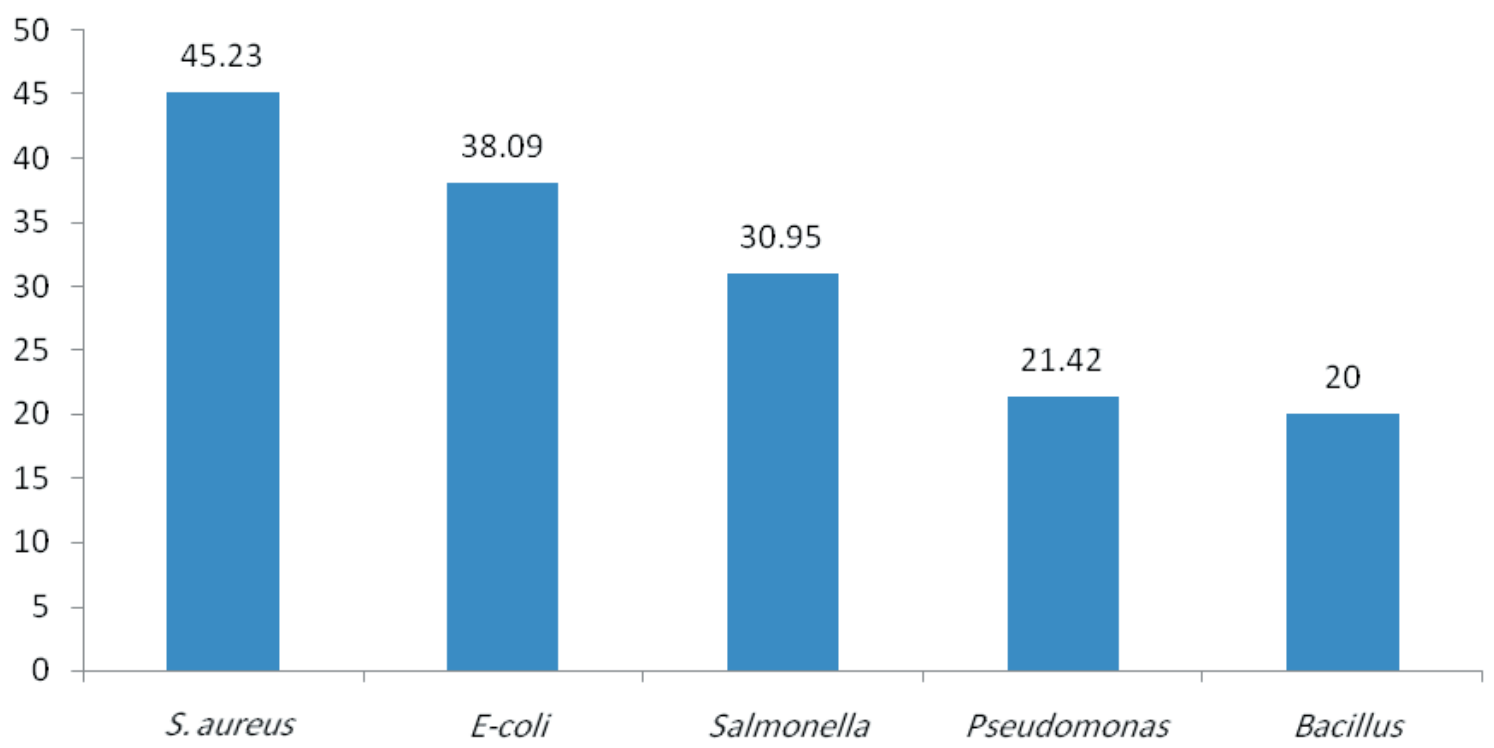

Figure 2: Bacteriological contamination of pani puri

Total viable count of bacteria (CFU)

The total viable count of bacteria in masala pani was found between $90-182 \times 10^{5} \mathrm{CFU}$ and $50-121 \times 10^{5} \mathrm{CFU}$ and solid matter masala varied between $80-130 \times 10^{5}$ CFU and $46-118 \times 10^{5}$ CFU from the crowded and noncrowded vendors respectively.

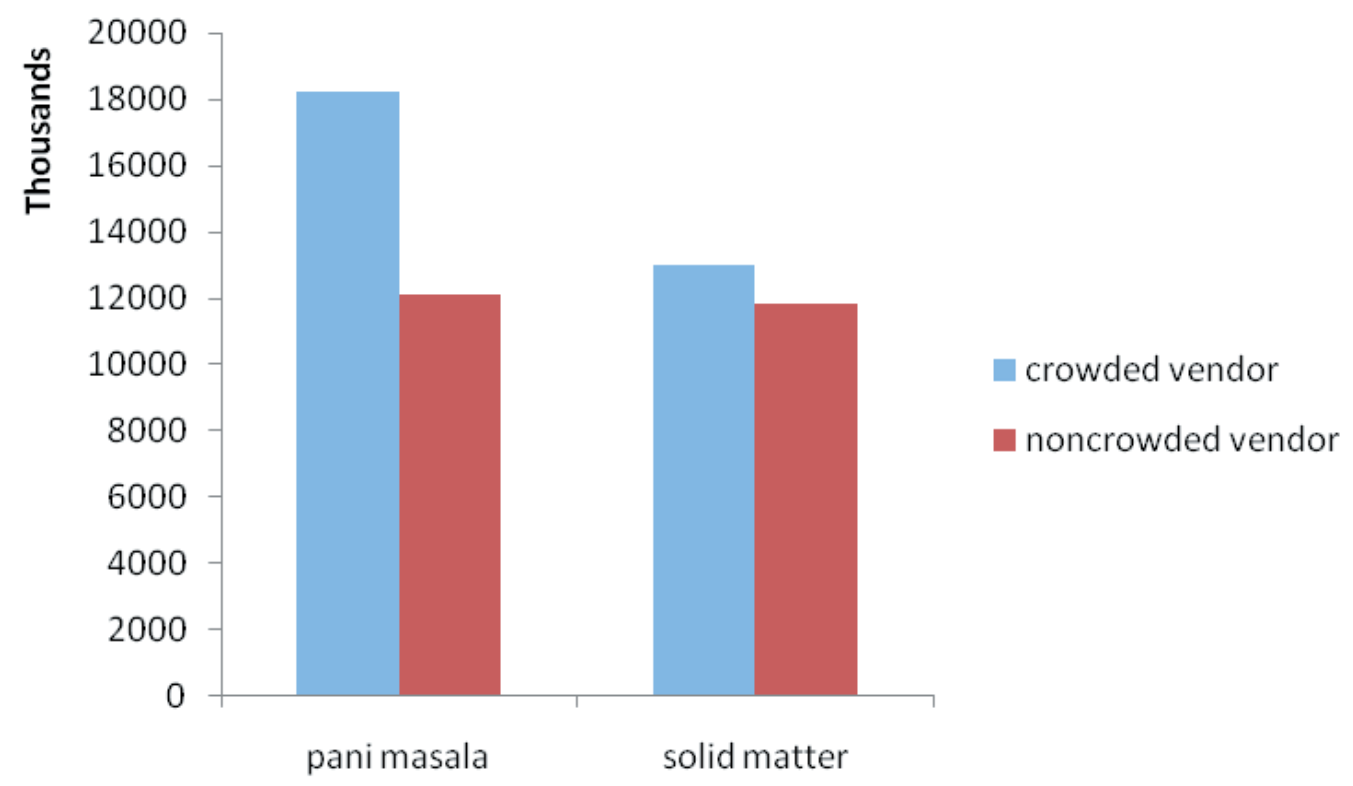

Figure 3: Total viable count of bacteria (CFU) in pani masala and solid matter 


\section{DISCUSSION}

Hygienic quality of street food vending has become an important public health issue and a great concern to everybody. Microbial contamination of ready-toeat foods and beverages sold by street vendors and hawkers has become a global health problem. In developing countries, fruit juices, drinks, meals and sold by street food vendors are widely consumed by millions of people (Tambekar et al. 2007).

Overall study indicated that most of the Pani puri samples were contaminated with variety of pathogenic bacterial contaminations. Many people have worked on the fact that Pani puri was contaminated with different bacterial pathogens because of various sources like improper handling of street foods, washing of utensils, dish cloths, stalls are at crowded place and movable stalls (Tamberkar et al. 2007). Microbial contamination may be linked to factors such as equipment and utensils with inadequate hygienic condition, uncovered utensils and garbage bin, irregularity of hand washing, in appropriate processing incomplete heating, use of contaminated water during preparation and washing or secondary contamination via contact with contaminated equipment's such as chopping boards, knives and serving wares (Adesiyun and Balbirsingh 1996). This might also implicate the processing and rinsing water as possible sources of contamination of pani puri sold by street vendors (Das et al. 2012). Similar results were obtained from the research conducted at Bharatpur (Khadaka et al. 2018).

In central Taiwan, 274 outbreaks of food-borne illness including 12,845 cases and 3 deaths were reported during 1991 to 2000 . Majority (62.4\%) of the outbreaks were caused by bacterial pathogens. The main etiologic agents were Bacillus cereus, Staphylococcus aureus, and Vibrio parahaemolyticus. The important contributing factor was improper handling of food. The implicated foods included seafood, meat products and cereal products (Chang \& Chen, 2003). In a study carried out from October 2004 to October 2005 in Catalonia, Spain, 181 outbreaks were reported; 72 were caused by Salmonella and 30 by Norovirus (NoV) (Crespo et al., 2005). In 2002, in 31 the Netherlands a national study of food-borne illness outbreaks was performed. A total of 281 food borne illness outbreaks were included. Most of these outbreaks were reported from nursing homes, restaurants, hospitals and day-care centres. The causative agents included Norovirus (54\%), Salmonella spp. (4\%), Rotavirus (2\%), and Campylobacter spp. (1\%) (Duynhoven et al. 2005). A study conducted in Qassim province, Saudi Arabia, analyzed the food-borne illness surveillance data for the year 2006. During the study period, 31 food-borne illness outbreaks comprising of 251 cases, were reported. The most common etiologic agent was Salmonella species, followed by Staphylococcus aureus. The previous findings are almost in accord with this study.

The bacterial contamination in Pani puri is because of the conditions under which it is prepared and vended. In most of the cases running water is not available at vending sites and thus hand and dish washing are usually done in buckets \& sometimes without soaps. (Das et al. 2012). E. coli, Staphylococcus, Klebsilella, Salmonella etc could be due to inadequate hand washing by food workers and the absence of good manufacturing practices. The occurrence of $P$. aeruginosa might be due to improper personal hygiene, unhygienic surrounding, vehicular transmission, and sewage. The presence of $S$. aureus was severe contamination through handling (Tambekar et al. 2007).

Crowded areas have a greater number of pathogens than non-crowded areas. There is potential health risks associated with initial contamination of foods by pathogenic bacteria as well as sub sequent contamination by vendors during preparation, handling, and cross contamination (Mosupye \& van Holy 2000). From all above discussion it was concluded that sample of Pani puri was contaminated with E. coli, Staphylococcus species., Salmanella species., Pseadomonas species., Klebsilella pneumonia which can cause various food borne infection.

The study cannot be related with the whole Dhanusha District and Janakpur Zone as it was carried specifically in town area of Janakpur only. Samples from all pani puri stalls in every street were not located due to impermanency of Pani puri stall and short availability of time during this research.

\section{CONCLUSION}

The present study concludes high level of contamination in different locations in one of the most popular Nepalese street food, Pani puri sold in Janakpur. Staphyloccoccus aureus and E. coli were the major contaminants of Pani puri. Foods sold by street vendors in Janakpur are contaminated with pathogenic bacterial organisms, which are likely to pose a potential hazard 
to consumers, an issue that needs to be addressed.

\section{ACKNOWLEDGEMENTS}

Authors are thankful to the chairman, staffs of the Model Multiple College for their praiseworthy support and providing laboratory facility during the work. We are also very thankful to the Pani puri seller for their help by providing samples.

\section{CONFLICT OF INTEREST}

The authors declare no conflict of interest.

\section{REFERENCES}

Abdussalam M, Kaferstein FK (1993). Safety of street foods. World Health Forum 14:191-194.

Adesiyun AA and Balbirsingh V (1996). Microbiological analysis of 'black pudding', a Trinidadian delicacy and health risk to consumers. Int J Food Microbiol 31: 283-299.

Barro N, Razack BA, Yollande I, Aly S, Tidiane OCA, Philippe NA, Comlan DS and Sababenedjo TA (2007). Street vended foods improvement: contamination mechanisms and application of food safety objective strategy: critical review. Pak J Nutr 6(1): 1-10.

Chang JM, and Chen TH (2003). Bacterial Foodborne Outbreaks in Central Taiwan, 1991- 2000. Journal of Food and Drug Analysis 11(1): 53-59.

Crespo PS, Hernández G, Echeíta A, Torres A, Ordóñez P and Aladueña A (2005). Surveillance of foodborne disease outbreaks associated with consumption of eggs and egg products: Spain, 2002-2003. European Communicable Disease Bulletin 10(6): E050616.2

Das M, Rath CC and Mohapatra UB (2012). Bacteriology of a most popular street food (pani puri) and inhibitory effect of essential oils on bacterial growth. Journal of Food Science and Technology 49(50): 564-571.

Dawson RJ and Canet C (1991). International activities in street foods. Food Control (2): 135-139.
Duynhoven Van PHTY, Jager DMC, Kortbeek ML, Vennema $\mathrm{H}$ and Koopmans GPMH, et al. (2005). A One-Year Intensified Study of Outbreaks of Gastroenteritis in the Netherlands Epidemiol Infect 133(1): 9-21.

Gormley FJ, Little CL, Rawal N, Gillespie IA, Lebaigue $S$ and Adak GK (2011). A 17-year review of foodborne outbreaks: describing the continuing decline in England and Wales (1992-2008). Epidemiol Infect 139(5): 688-99.

Khadka S and Adhikari S et al. (2018). Bacterial contamination and risk factors associated with street vended Pani puri sold in Bharatpur, Nepal. Int J Food Res 5: 32-38.

Mankee A, Ali S, Chin A, Indalsingh R and Khan R, et al. (2003). Bacteriological Quality of doubles sold by street vendors in Trinidad and the attitudes, knowledge and perceptions of the public about its consumption and health risk. Food Microbiol 20: 631-639.

Mensah P, Manu DY, Darko KO and Ablordey A (2002). Streets foods in Accra, Ghana: how safe are they? Bulletin of World Health Org 80(7): 546-554.

Mosupye FM and Van HA (2000). Microbiological hazard identification and exposure assessment of street food vending in Johannesburg, South Africa. International Journal of Food Microbiol 61: 137-145.

Saxena G and Agarwal M (2013). Microbial quality assessment of street-vended Golgappa and Bhelpuri sold in Jaipur city of Rajasthan. Int J Food Nutr Sci 2(1): 71-77.

Tambekar DH, Shirsat SD, Suradkar SB, Rajankar PN, and Banginwar YS (2007). Prevention of transmission of infectious disease: Studies on hand hygiene in health-care among students. Continental Journal of Biomedical Sci 1: 6-10. 